\title{
Genes mediating programmed cell death: an immunohistochemical study of bcl-2, c-myc and p53 expression in colorectal neoplasia
}

\author{
Nigel Scott, Ian Martin, Andrew S Jack, Michael F Dixon, Philip Quirke
}

\begin{abstract}
Aims-To describe the expression of three genes involved in the regulation of cell proliferation and programmed cell death (apoptosis) in normal, dysplastic and malignant large bowel epithelium, and to relate any alterations to important biological and clinical variables.

Methods-Immunohistochemistry was used to assess bcl-2, c-myc and p53 gene expression in 70 colorectal carcinomas, 36 adenomas and three samples of normal mucosa.
\end{abstract}

Results-Bcl-2 and c-myc protein were detected in all samples of normal mucosa and most adenomas. P53 was never found in normal mucosa and was expressed in only $5 \%$ of adenomas. Sixty nine of 70 carcinomas expressed c-myc protein; p53 was found in $46 \%$ and bcl-2 was present in $35 \%$. Bcl-2 expression correlated with a higher degree of tumour differentiation whereas the opposite was true for c-myc. Strong staining for c-myc protein predicted survival in univariate analysis. No correlation was found between p53 and bcl-2 expression.

Conclusions-While c-myc and bcl-2 proteins are overexpressed at an early stage of the large bowel adenoma-carcinoma sequence, alterations to the p53 protein level only occur as a late event in large, highly dysplastic adenomas and carcinomas. Bcl-2 may therefore protect the growing adenoma against excessive programmed cell death and mutated p53 may play a similar role in carcinomas. In vitro there is a reciprocal relation between p53 and bcl-2 expression. This could not be confirmed in vivo. Similarly, there was no relation between bcl-2 and c-myc status, despite evidence that these proteins cooperate to cause neoplastic transformation. $\mathrm{C}-\mathrm{myc}$ may be a prognostic indicator in large bowel cancer. There is no evidence in the present series that bcl-2 status will affect survival.

(F Clin Pathol: Mol Pathol 1996;49:M151-M158)

Keywords: colorectal carcinoma, bcl-2, c-myc, p53, survival.

Tumour growth, whether benign or malignant, results from an imbalance of cell production and cell loss. While there are many studies of cell proliferation in the literature, little is known about the other side of the equation. In 1977 , Steel calculated that in some malignancies, including large bowel cancer, the rate at which new cells were produced was almost equalled by the rate of spontaneous cell loss. ${ }^{1}$ Consequently, any factor which alters tumour cell loss, either by increasing cell death or exfoliation, could have a profound influence on tumorigenesis.

One of the most important mechanisms of tumour cell loss is apoptosis or programmed cell death. ${ }^{2}$ This is an active cellular process occurring both physiologically and pathologically in response to a number of specific stimuli. A low level of apoptosis is seen in the normal large bowel, where apoptotic bodies are commonly observed in the surface epithelium. ${ }^{3}$ In disease states, such as drug induced colitis and graft versus host disease, the level of apoptosis may be increased. ${ }^{45}$ Apoptotic bodies are also commonly seen in adenomas and malignant large bowel tumours, where they may be numerous and no longer confined to the epithelial surface.

Recent work suggests that several genes are involved in mediating programmed cell death. ${ }^{6}$ Intriguingly, some of these are already known to be regulators of cell proliferation and differentiation, suggesting that the decision whether a cell divides or dies involves closely related pathways. Three particularly important mediators of apoptosis are the oncogenes bcl-2 and c-myc and the tumour suppressor gene p53.

Bcl-2, located at chromosome locus $18 \mathrm{q}$, encodes a 26 kilodalton protein which resides in the mitochondrial membrane, endoplasmic reticulum and nuclear envelope. ${ }^{78}$ When expressed in lymphocytes it prolongs cell survival and rescues them from apoptosis induced by a variety of agents. ${ }^{9}$ In transgenic mice overexpression results in polyclonal expansion of $B$ lymphocyte populations and, subsequently, the development of monoclonal, high grade lymphoma $^{10}{ }^{11}$ Neoplastic transformation in these mice is frequently accompanied by activation of the c-myc oncogene, suggesting cooperation between bcl-2 and c-myc in tumorigenesis. ${ }^{11}$ Supporting evidence for this hypothesis has been found in vitro. ${ }^{12}{ }^{13}$ One possible reason for the cooperative effect between bcl-2 and c-myc, is the ability of bcl-2 to inhibit programmed cell death induced by the $p 62^{c-m y c}$ oncoprotein. Recently, bcl-2 expression has been described in both normal and neoplastic colonic epithelium. ${ }^{14}{ }^{15}$ Abnormalities of the 
bcl-2 gene may therefore play a role in epithelial tumours as well as haematological malignancy.

C-myc, the gene encoding a 62 kilodalton nuclear protein, is frequently deregulated in colorectal tumours. ${ }^{16}{ }^{17}$ Sixty to $80 \%$ of carcinomas express elevated levels of myc protein and RNA transcript, similar levels also being found in a proportion of adenomas. While the c-myc gene is intimately involved in regulating cell proliferation, recent studies suggest that under certain circumstances it will also trigger apoptosis. ${ }^{18}$ This is particularly the case when a cell receives conflicting signals to replicate and become quiescent at one and the same time.

A third gene implicated in the control of both cell division and programmed cell death is the p53 tumour suppressor gene. Located on the short arm of chromosome 17, p53 is inactivated in over $60 \%$ of carcinomas by a combination of chromosomal deletion and point mutation. ${ }^{19} 20$

In large bowel cancer many of these mutations are missense mutations, producing an altered protein with an extended half-life which accumulates in the cell nucleus and becomes demonstrable by immunocytochemistry. ${ }^{21}$ This provides a simple immunohistochemical marker by which most, though not all, p53 mutations can be identified. ${ }^{22}$ Shaw et $a l^{3}$ recently showed that wild-type $\mathrm{p} 53$, in addition to causing cell cycle arrest, can also stimulate programmed cell death in a colorectal carcinoma cell line. This effect may be at least partially mediated by bcl-2, as p53 is capable of down-regulating the bcl-2 gene as well as inducing bax expression, a bcl-2 related protein with apoptosis promoting properties. ${ }^{24}$ P53 is also important in stimulating apoptosis in response to radio- and chemotherapy. ${ }^{25} 26$

Thus, there is a complicated molecular network by which programmed cell death and cell replication are integrated in the normal cell. Key elements in this regulatory system are provided by the bcl-2, c-myc and p53 genes, the last two of which are commonly altered in colorectal tumours. Little is known about bcl-2 expression in large bowel cancer as yet, although two recent studies suggest that the protein is present in a proportion of carcinomas. ${ }^{14}{ }^{15}$ In addition, there is evidence that bcl-2 and c-myc cooperate in some tumours to produce neoplastic transformation and that p53 may influence bcl-2 expression at the level of gene transcription.

In two previous reports we described overexpression of p53 tumour suppressor protein in $46 \%$ and $5 \%$ of colorectal carcinomas and adenomas, respectively. ${ }^{27}$ We have now extended our study of large bowel carcinogenesis by looking for alterations in the expression of two oncogenes, c-myc and bcl-2. The reason for choosing these genes was twofold. Firstly, bcl-2 expression in the adenoma-carcinoma sequence is poorly documented and its relation to prognosis has not been evaluated fully. Secondly, as described above, bcl-2, c-myc and p53 are all intimately involved in the intracellular control of programmed cell death and, under certain circumstances, seem to act in a coordinated fashion. In this study we have specifically looked for in vivo evidence of oncogene cooperation and reciprocity of $\mathrm{p} 53 / \mathrm{bcl}-2$ expression in large bowel tumours.

\section{Methods}

PATIENT POPULATION

Carcinomas

Seventy patients with primary diagnoses of large bowel adenocarcinoma treated between 1983 and 1990 were selected at random. All patients were treated at the Leeds General Infirmary by wide surgical excision. Adjuvant therapy was not given routinely. Mean age was 68 years and $56 \%$ were male. Fifty seven per cent of tumours were located in the rectum, $77 \%$ distal to the splenic flexure and $23 \%$ in the proximal colon.

Survival data were available for 55 of the 70 patients. Median follow up was 24 months (range 1-76 months) and overall actuarial five year survival was $45 \%$. Cancers were staged according to Dukes: $7 \%$ were stage A, $43 \%$ stage $B$ and $50 \%$ stage $C$. Tumour grade was assessed according to the usual criteria and classified as well or poorly differentiated. Forty eight $(69 \%)$ cancers were well differentiated and twenty two (31\%) were poorly differentiated. Two grades were used rather than three according to the recommendations of Jass and Morson, and the UKCCCR. ${ }^{29}{ }^{30}$ DNA flow cytometry was carried out on paraffin wax embedded tumour tissue as described by Hedley et $a l .{ }^{31} \mathrm{~A}$ mean number of 1.96 blocks per case was analysed and mean CV (coefficient of variation) was $5.8 \%$. Cell proliferation was measured in DNA diploid cancers only ( $\mathrm{n}=$ 28) using the Paral cell cycle analysis programme. ${ }^{32}$ The proliferative fraction was expressed as the sum of cells in $S$ and $G_{2} / M$ phases of the cell cycle. DNA aneuploidy was defined using standard international criteria. ${ }^{33}$

\section{Adenomas}

Twenty one sporadic adenomas and 15 polyps from three patients with familial adenomatous polyposis (FAP) were identified from departmental records. Nine of the sporadic adenomas were benign polyps retrieved from colectomy specimens containing carcinoma. Focal malignant change was identified in a further two adenomas. The remaining 10 polyps were removed from non-cancerous bowel. Dysplasia was graded as mild, moderate or severe as recommended by Konishi and Morson. ${ }^{34}$

\section{Metaplastic polyps and normal mucosa}

Five metaplastic polyps removed by endoscopic polypectomy and normal mucosa from three patients undergoing colectomy for angiodysplasia $(n=1)$ and chronic constipation $(n=2)$ were retrieved from the departmental archives.

BCL-2

Immunostaining for bcl-2 protein was performed on 60 colorectal carcinomas from 70 of the patients described above. Formalin fixed, paraffin wax sections, $4 \mu \mathrm{m}$ thick, were cut and mounted on aminopropyl-triethoxysilane coated 


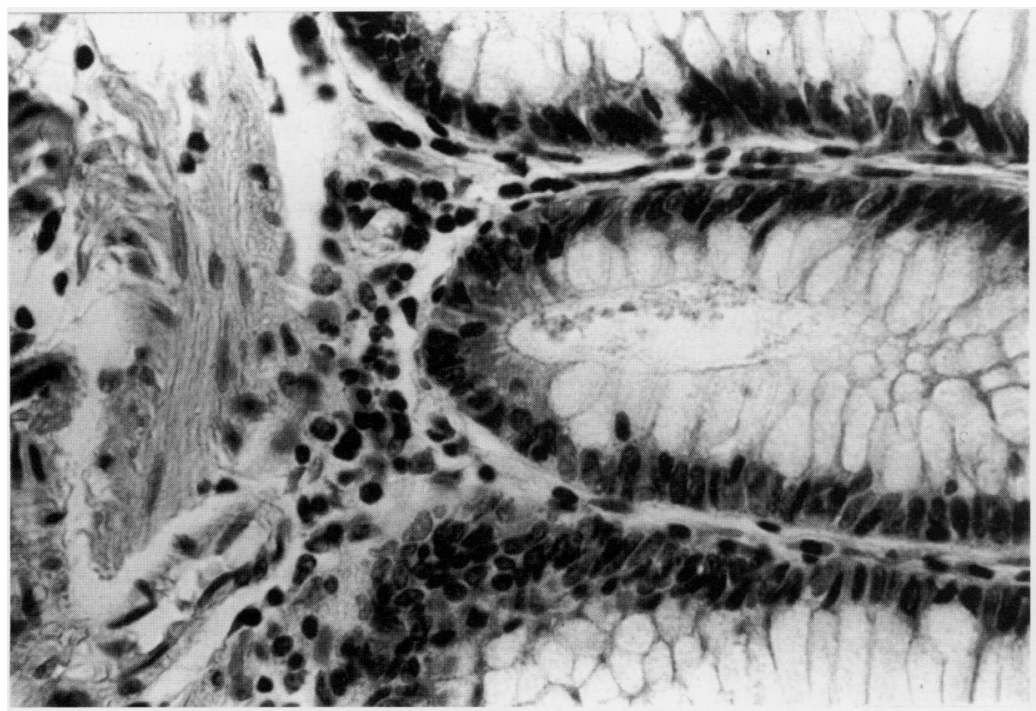

Figure 1 Cytoplasmic staining for bcl-2 protein at the base of a normal colonic crypt $(\times 400)$.

slides. Endogenous peroxidase activity was blocked by immersion in methanol $/ \mathrm{H}_{2} \mathrm{O}_{2}$ for 20 minutes and sections were microwaved in citrate buffer $(2.1 \mathrm{~g}$ citric acid in 1 litre distilled water, $\mathrm{pH}$ 6.0) for five minutes. Sections were incubated with the following: antibody directed against bcl-2 for one hour (bcl-2-124; Dako, Glostrup, Denmark); biotinylated rabbit anti-mouse immunoglobulin for 30 minutes; and streptavidin peroxidase conjugate for 30 minutes. The primary antibody was used at a dilution of 1 in 50 in Tris buffered saline (TBS) and antibody binding was visualised using diaminobenzidine. Bcl-2-124 recognises the 26 kilodalton bcl- 2 protein in western blotting experiments. ${ }^{35}$

Omission of primary antibody was used as a negative control, while normal mucosa or lymphocytes, or both, within the test section provided an "internal" positive control. Staining was graded according to intensity and distribution within the tumour. The former was scored as follows: $0=$ negative; $1=$ weak; and 2 $=$ strong. The latter was assessed semiquantitively as less than $5 \%$ tumour cells positive; 5 to $33 \%$ positive; between 33 and $66 \%$ positive, and greater than $66 \%$ positive.

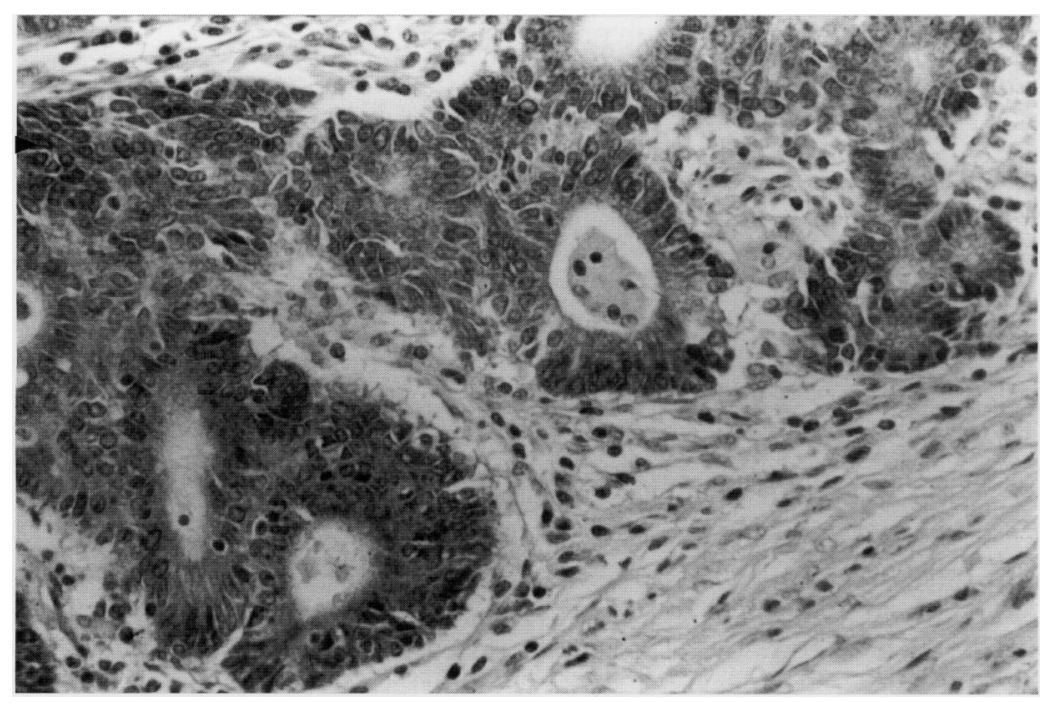

Figure 2 Overexpression of bcl-2 protein in a colorectal adenocarcinoma $(\times 400)$.
For the purposes of correlation with clinicopathological variables, including p53 and c-myc protein expression, carcinomas were divided into two groups; those showing little or no staining (that is, $<5 \%$ tumour cells positive) and those in which staining was more extensive. Statistical significance was tested using $\chi^{2}$ with Yates' correction and Kendall's rank correlation.

Immunohistochemistry was also carried out on 34 adenomas and five metaplastic polyps. Fifteen adenomas were from three patients undergoing conservative proctocolectomy for FAP. One of the sporadic adenomas contained an area of invasive carcinoma. Six microadenomas (dysplasia affecting five crypts) were also identified in the FAP samples and assessed for bcl-2 immunoreactivity.

C-MYC

Immunostaining for $\mathrm{p} 62^{\mathrm{c}-\mathrm{myc}}$ was done on all 70 carcinomas and on 21 sporadic colorectal adenomas. No FAP adenomas were examined for myc expression. The antibody used was $1-6$ E 10 and the method used was identical with that described for bcl- $2 .{ }^{36}$ In addition to scoring intensity and extent of staining, the intracellular distribution of protein was also assessed, and classified as either cytoplasm predominant, mixed nuclear and cytoplasmic, or nucleus predominant. For the purposes of analysis, carcinomas were divided into those showing diffuse, strong staining $(>5 \%$ cells positive) and those showing focal or weak/ equivocal reactions.

\section{$\mathrm{P} 53$}

Data for $\mathrm{p} 53$ overexpression were derived from two previous studies of 100 colorectal carcinomas and 40 adenomas. ${ }^{27}{ }^{28}$ This included 68 of 70 carcinomas examined in the present series for bcl-2 and c-myc expression. The primary antibodies used to detect $\mathrm{p} 53$ in these studies were $\mathrm{Pab} 421$ and 1801, and staining was scored as positive when over $5 \%$ of tumour cell nuclei expressed protein. ${ }^{37} 38$

\section{Results}

BCL-2

Twenty one $(35 \%)$ of 60 carcinomas and 18 $(95 \%)$ of 19 adenomas expressed p26 $6^{\text {bl-2 }}$ in a substantial number of tumour cells-that is, $>5 \%$. The difference is statistically significant $\left(\mathrm{p}<0.05 ; \chi^{2}\right)$. Staining was cytoplasmic and granular. No nuclear staining was seen. Adjacent, non-dysplastic "transitional" mucosa and normal mucosa from three patients undergoing colectomy for non-neoplastic conditions showed immunoreactivity restricted to a small number of cells at the base of each crypt (fig 1). Other normal cell types which expressed bcl-2 protein included lymphocytes, plasma cells, and ganglion cells. Smooth muscle cells, fibroblasts and vascular endothelium were negative.

Six $(10 \%)$ tumours had particularly strong expression, with protein identified in more than two thirds of the malignant cells (fig 2). Twenty one $(35 \%)$ showed staining in more than $5 \%$ of tumour cells; $32 \%(19 / 60)$ had only occasional positive cells (that is, $<5 \%$ ); and 


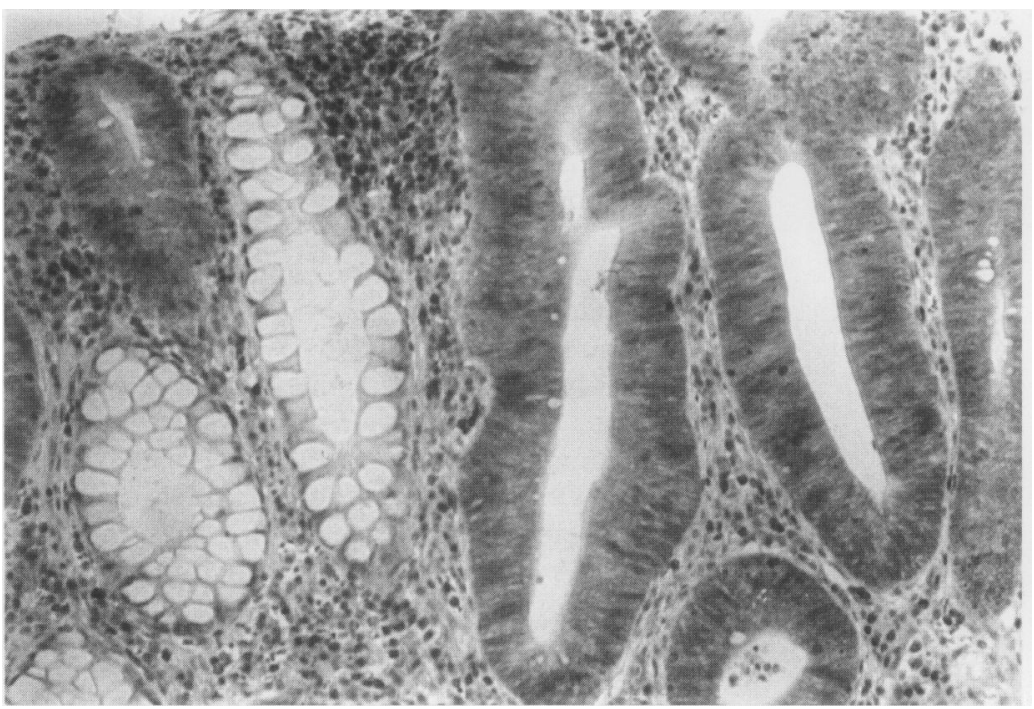

Figure 3 Increased expression of bcl-2 protein in a tubular adenoma. Note the lack of staining in adjacent non-dysplastic crypts $(\times 400)$.

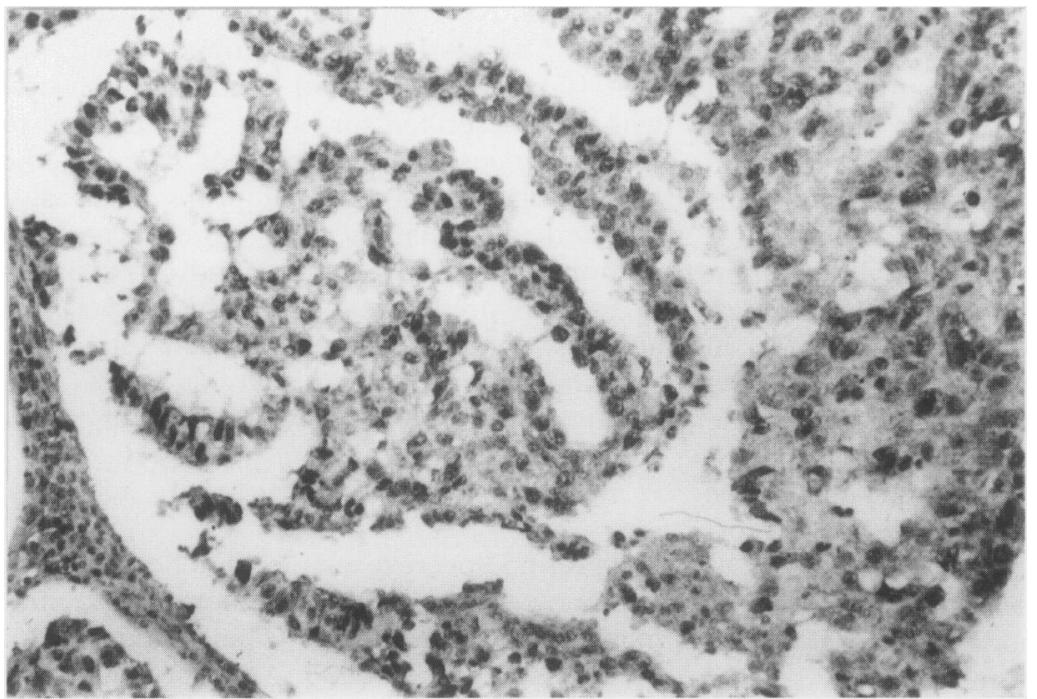

Figure 4 Nuclear staining for c-myc oncoprotein in a colorectal adenocarcinoma $(\times 400)$.

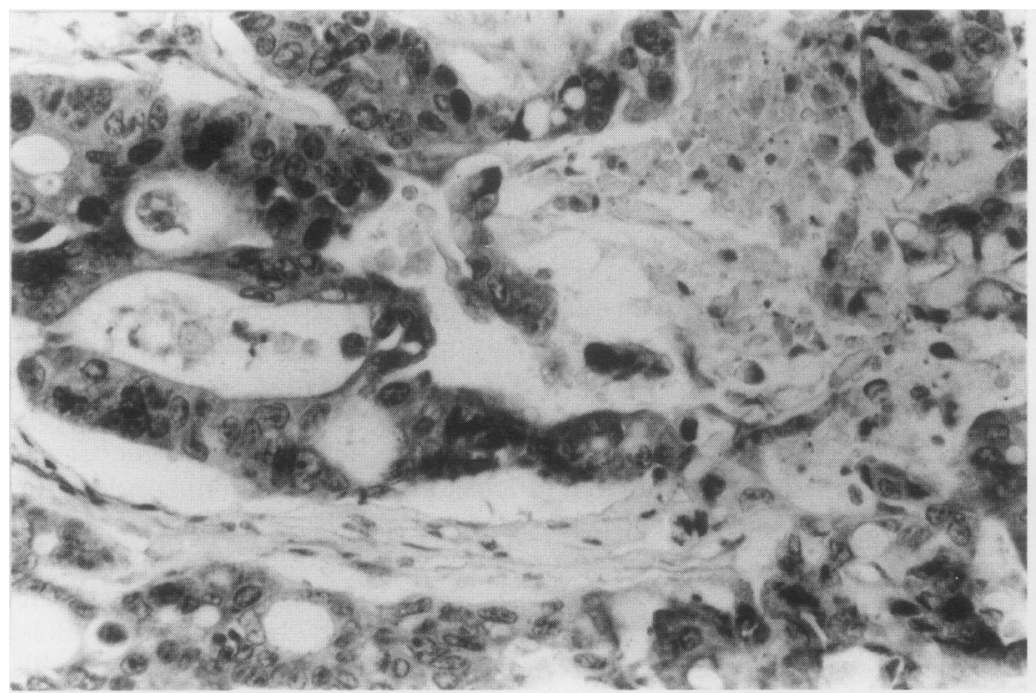

Figure 5 Mixed nuclear and cytoplasmic staining for c-myc oncoprotein in a colorectal adenocarcinoma $(\times 400)$. between bcl-2 expression and c-myc or p53 status. Staining was more frequent, however, in well differentiated carcinomas $\left(\mathrm{p}=0.02 ; \chi^{2}\right)$. Only three $(14 \%)$ of 21 poorly differentiated tumours overexpressed bcl-2 compared with $17(44 \%)$ of 39 low grade lesions. A trend was also seen towards higher levels of protein in early stage cancers, but this did not reach statistical significance $\left(\mathrm{p}=0.09 ; \chi^{2}\right)$. Survival analysis showed no significant difference between the two groups, nor was there any relation between bcl- 2 staining and cell proliferation.

Staining in the adenomas was more extensive than in the carcinomas, although this varied with the degree of dysplasia. Four of five adenomas showing mild dysplasia demonstrated strong cytoplasmic staining, whereas none of three severely dysplastic polyps did so. One polyp showing severe dysplasia contained only occasional positive cells. Interestingly, this was an adenoma which had undergone malignant change and overexpressed p53 protein. Adenomas exhibiting moderate dysplasia showed a pattern of staining intermediate between mild and severely dysplastic lesions. This correlation between the degree of dysplasia and bcl-2 expression was also evident within individual tumours, where more dysplastic areas stained less intensely than well differentiated areas.

Overexpression of $\mathrm{p} 26^{\mathrm{bcl}-2}$ in adenomas was characterised not only by intense cytoplasmic staining, but more importantly by the extension of staining up the crypt sides into the middle and upper third crypt compartments (fig 3). In some cases bcl-2 could also be visualised in the surface epithelium. Reminiscent of normal mucosa, however, expression in some polyps was often most intense at the adenomatous crypt base.

Six microadenomas from the patients with FAP also showed raised bcl-2 protein levels. No difference in staining was seen, however, between the background mucosa of the FAP colon and either normal mucosa or mucosa from patients with sporadic adenomas.

Five metaplastic polyps showed staining confined to cells at the crypt base identical with that seen in normal mucosa. None of these polyps exhibited dysplasia.

C-MYC

Of the 70 carcinomas, only one failed to express $\mathrm{p} 62^{\mathrm{c}-\mathrm{myc}}$. Thirty seven per cent showed weak or equivocal staining, $33 \%$ moderate and $28.6 \%$ strong staining. In $10 \%$ of cases the staining was predominantly nuclear (fig 4). Forty five per cent showed cytoplasmic immunoreactivity, while the remainder expressed p62 $2^{\text {c-myc }}$ in both the nucleus and cytoplasm (fig 5). Table 1 shows the relation between c-myc expression and several clinicopathological variables. A trend was seen towards stronger staining in poorly differentiated carcinomas and tumours metastatic to regional lymph nodes (Dukes' stage C). Only the latter reached statistical significance however. Survival analysis showed shorter disease-free survival of patients with strongly staining tumours $(\mathrm{p}<$
$33 \%(20 / 60)$ were completely negative by immunohistochemistry. The relation between significant immunoreactivity $(>5 \%$ tumour cells positive) and clinicopathological variables is shown in table 1 . No correlation was found 
Table 1 p26 $6^{\text {bcl-2 }} p 62^{c-m y c}$ and p53 staining: clinicopathological correlations in colorectal adenocarcinoma

\begin{tabular}{|c|c|c|c|}
\hline $\begin{array}{l}\text { Clinicopathological } \\
\text { variables }\end{array}$ & $\begin{array}{l}p^{26^{b c l-2}} \text { positive } \\
n(\%)\end{array}$ & $\begin{array}{l}p 62^{c-m y c} \text { positive } \\
n(\%)\end{array}$ & $\begin{array}{l}\text { p53 positive } \\
n(\%)\end{array}$ \\
\hline \multicolumn{4}{|l|}{ Site } \\
\hline Proximal & $5 / 17(25 \%)$ & $12 / 17(75 \%)$ & $9 / 30(30 \%)$ \\
\hline Distal & $17 / 43(38 \%)$ & $31 / 53(61 \%)$ & $36 / 70(52 \%)$ \\
\hline \multicolumn{4}{|l|}{ Differentiation } \\
\hline Poor & $3 / 21(14 \%)^{\star}$ & $16 / 22(73 \%)+$ & $13 / 25(52 \%)$ \\
\hline Well & $18 / 39(45 \%)$ & $27 / 48(56 \%)$ & $32 / 75(43 \%)$ \\
\hline \multicolumn{4}{|l|}{ Dukes' stage } \\
\hline A & $2 / 4(50 \%) \ddagger$ & $2 / 5(40 \%) \uparrow$ & $1 / 4(25 \%)$ \\
\hline B & $12 / 26(44 \%)$ & $15 / 30(50 \%)$ & $22 / 50(44 \%)$ \\
\hline C & $7 / 30(23 \%)$ & $26 / 35(76 \%)$ & $22 / 46(49 \%)$ \\
\hline \multicolumn{4}{|l|}{ DNA } \\
\hline Aneuploid & $12 / 33(37 \%)$ & $23 / 40(57 \%)$ & $28 / 52(53 \%)$ \\
\hline Diploid & $9 / 27(32 \%)$ & $20 / 30(68 \%)$ & $17 / 48(36 \%)$ \\
\hline \multicolumn{4}{|l|}{ p53 status } \\
\hline Positive & $9 / 25(36 \%)$ & $21 / 29(72 \%)$ & \\
\hline Negative & $11 / 33(33 \%)$ & $22 / 40(55 \%)$ & \\
\hline \multicolumn{4}{|l|}{ c-myc status } \\
\hline Positive & $10 / 35(29 \%)$ & & $21 / 43(49 \%)$ \\
\hline Negative & $10 / 24(42 \%)$ & & $8 / 26(31 \%)$ \\
\hline Total & $35 \%$ & $61.5 \%$ & $45 \%$ \\
\hline
\end{tabular}

${ }^{\star} \mathrm{p}=0.02 ; \mathrm{tp}=0.19 ; \neq \mathrm{p}=0.09 ; \S \mathrm{p}=0.03\left(\chi^{2}\right.$ test with Yates' correction).

Two cases stained for bcl-2 and one case stained for c-myc lack p53 data, while one case analysed for $\mathrm{p} 62^{\mathrm{c}-m y c}$ lacks bcl-2 expression data.

0.04 ), but the pattern of staining-that is, nuclear versus cytoplasmic, did not influence prognosis.

All 21 adenomas exhibited some degree of immunostaining for c-myc. This was intense in five. The majority showed a mixture of nuclear and cytoplasmic expression, although nuclear staining was particularly conspicuous at the crypt base (fig 6). There was no obvious relation between intensity of staining and polyp size, architectural type or degree of dysplasia. Expression was also seen in normal mucosa along the full length of the crypt, in lymphocytes and plasma cells, and in proliferating fibroblasts.

\section{P53}

Data for p53 staining were derived from two previous studies. ${ }^{27}{ }^{28}$ Forty six per cent of carcinomas and $5 \%$ of adenomas overexpressed p53 protein. All staining was nuclear. Details of the relation between p53 and colorectal tumour behaviour have been reported previously. ${ }^{27} 28$

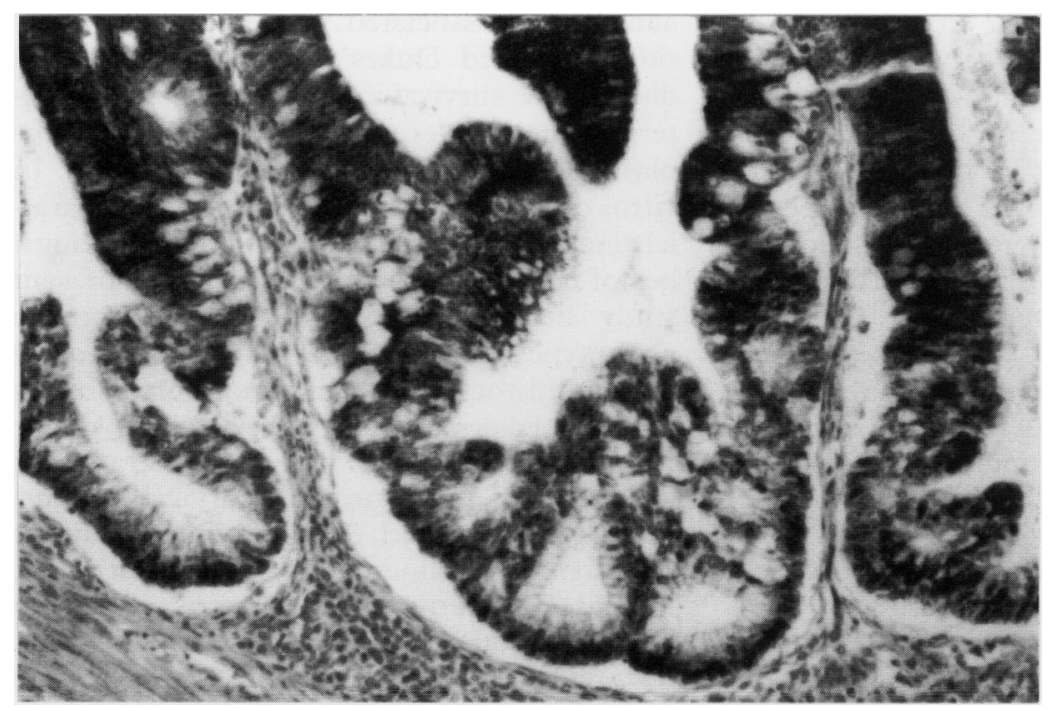

Figure 6 Mixed nuclear and cytoplasmic staining for c-myc oncoprotein in a colorectal adenoma. Note nuclear staining at the crypt base and cytoplasmic staining further up the crypt $(\times 400)$.
No correlation was found in the present study between p53, bcl-2 and c-myc status (table 1). Increased expression of one did not seem to be associated with overexpression of another.

\section{Discussion}

Carcinomas of the large bowel develop as a result of the accumulation of multiple genetic insults, many of which involve oncogenes and tumour suppressor genes. ${ }^{39}$ In the normal cell these genes function in the regulation of cell proliferation and differentiation, and tumorigenesis is thought to occur as a consequence of deregulated cell division. More recently, however, attention has focused on another class of oncogene which promotes neoplastic transformation by extending cell survival. Genes which play a role in the regulation of cell death by apoptosis include bcl-2, bcl-x, bax, c-myc, p53, and ras. ${ }^{6}$ Apoptosis is a common mode of cell loss in tumours, where it occurs both spontaneously and as a result of cytotoxic therapy. ${ }^{2}$ In some cancers the rate of spontaneous cell loss even approaches that of cell production. Consequently, genetic changes which protect a cell against programmed cell death may have a significant effect not only on the rate at which a tumour grows but also on the ability of tumour cells to survive in a hostile environment - for example, within metastases. ${ }^{40}$ Several studies also suggest that alterations in genes regulating apoptosis influence the response of a cancer to chemotherapy. ${ }^{25} 264142$ Determining the status of p53 or bcl-2 in tumours may therefore eventually provide a more rational approach to adjuvant therapy. ${ }^{43}$

The present study describes the immunohistochemical detection of the products of the bcl-2 and c-myc genes in a series of large bowel adenomas and carcinomas, and relates their expression to a third protein, p53. All of these genes influence apoptosis in vitro and p53 in particular seems to be an important regulator of programmed cell death in large bowel epithelium. ${ }^{23}{ }^{44}$

In normal and transitional mucosa $\mathrm{p} 26^{\mathrm{bcl}-2}$ was restricted to the cytoplasm of a small number of cells at the crypt base. This is the location of the colonic crypt stem cells and it may be that bcl-2 is important in maintaining the integrity of this vital cell population. Identical staining was described by Lu et $a l^{45}$ and Hockenberry et $a l^{46}$, who confirmed their immunohistochemical findings by RNA in situ hybridisation. In contrast to normal mucosa, most adenomas exhibited increased protein expression with staining no longer confined to the crypt base, but extending into the upper half of the crypt. Even microadenomas from patients with FAP showed increased expression. Up-regulation of bcl-2 therefore seems to be an early feature of adenoma formation.

Previous molecular studies have identified mutation of the APC gene and DNA hypomethylation as initiating events in the development of adenoma. ${ }^{47}$ The present study suggests that overexpression of bcl-2 is also associated closely with the earliest stages of neoplastic transformation in the large bowel. In this con- 
text it would be of interest to determine whether aberrant crypt foci also overexpress bcl-2, as these probably represent the earliest morphological lesion in large bowel carcinogenesis. ${ }^{48}$

The extension of bcl-2 staining up the adenomatous crypt parallels the expanded proliferative compartment in these tumours. ${ }^{49}$ As many of the regulators of cell proliferation, such as c-myc, are also potent inducers of apoptosis and c-myc expression is abnormal in adenomas, up-regulation of bcl-2 may be necessary to protect the neoplastic clone from programmed cell death and permit adenoma growth. This would be consistent with the cooperative effect of bcl-2 and c-myc in vitro. Alternatively, it could be argued that raised bcl-2 expression is a secondary event and simply reflects increased cell proliferation. In 1986, Reed et a ${ }^{50}$ showed that the bcl-2 gene is cell cycle regulated, although this has been disputed subsequently. ${ }^{51}$ While we cannot discount this mechanism in adenomas, the lack of a consistent relation between cell proliferation measurements and bcl-2 status in carcinomas in the present study suggests that overexpression may also occur independently of the cell cycle.

In carcinomas overexpression of $\mathrm{p} 26^{\mathrm{bcl}-2}$ was absent in all but $35 \%$ of tumours and only $10 \%$ showed diffuse immunoreactivity. This is different to the results found in two other immunohistochemical studies, in which over two thirds of carcinomas stained positively. ${ }^{14}{ }^{15}$ Possible reasons for this discrepancy include differences in staining methods and systematic bias in the interpretation of positive cases. Kaklamanis et $a P^{2}$, using identical methods to those in the present study, also found bcl-2 protein in a minority of cancers (25\%). Deregulation of the bcl-2 gene may be a key event in the progression of this subgroup of tumours. Interestingly, the majority of cancers overexpressing bcl-2 were well differentiated, while poorly differentiated tumours rarely expressed protein. This may be explained either by restriction of bcl-2 transcription by the differentiation state of the tumour cell or a direct positive effect of bcl- 2 on differentiation. Hanada et $a \bar{l}^{3}$ recently showed that bcl-2 levels in a neuroblastoma cell line were regulated by the differentiation state of the tumour cell. Similarly, p26 ${ }^{\text {bcl-2 }}$ levels were higher in well differentiated thyroid tumours and breast carcinomas. ${ }^{54} 55$ Therefore, there is supporting evidence in several tumour systems that bcl-2 activity is linked to differentiation.

One third of cancers, while not exhibiting diffuse staining, did nevertheless contain occasional positive cells. This raises the intriguing possibility that in these tumours, bcl-2 staining identifies a small group of "neoplastic stem cells", analogous to bcl- 2 positive cells at the base of the normal colonic crypt and capable of clonal proliferation in cell culture.

Why do so many early stage adenomas show up-regulated bcl-2 expression while so few carcinomas stain positively? One possible reason is that as adenomas progress and evolve into malignant tumours, they acquire other genetic lesions which render bcl-2 redundant. Our own and other studies have documented alterations to p53 gene activity in severely dysplastic adenomas and 40 to $70 \%$ of carcinomas. ${ }^{22}{ }^{28-58}$ As p53 also functions in apoptotic pathways in the cell, inactivation by mutation or allele loss may replace bcl-2 in protecting the cell against programmed cell death. Alternatively, accumulation of wildtype or mutant p53 protein, both of which are described in colorectal tumours, may switch off bcl-2 transcription directly. Negative regulation of bcl- 2 by $\mathrm{p} 53$ has been described recently by several workers. ${ }^{245}$ If either of these were the case, one would expect a reciprocal relation between p53 and bcl-2 overexpression in carcinomas. While this has been documented in breast carcinoma, we could not confirm this in the large bowel. ${ }^{55}$ Sinicrope $e t$ al ${ }^{15}$ reported similar findings in which the status of $\mathrm{p} 53$ and bcl-2 was unrelated in large bowel cancers but did seem to show a negative correlation in pre-malignant adenomas. In the current series only one adenoma overexpressed $\mathrm{p} 53$, making this kind of analysis impossible. Interestingly, however, this was the only polyp to show $<5 \%$ tumour cell positivity for bcl-2.

A further genetic lesion which may supplement bcl-2 in extending cell survival is mutation of the ras oncogene, which also seems to have an anti-apoptotic effect. ${ }^{60}$ As over $40 \%$ of large adenomas and adenocarcinomas possess a mutated ras gene, this is therefore another potential candidate for inhibiting programmed cell death in the large bowel. ${ }^{61}{ }^{62}$

The results of immunohistochemical staining for $\mathrm{p} 62^{\mathrm{c}-\mathrm{myc}}$ are similar to those reported by other authors. ${ }^{63}{ }^{64}$ Although primarily a nuclear phosphoprotein, cytoplasmic staining is a frequent phenomenon in large bowel tumours and probably reflects a combination of fixation artefact and genuine redistribution owing to as yet undefined protein alterations. ${ }^{63}$ We have found identical staining patterns with a second monoclonal antibody (1-9E10) recognising a different part of the c-myc protein, suggesting that cross-reaction with another unrelated cellular constituent is unlikely. Strong immunoreactivity was associated with poor differentiation, advanced Dukes' stage, and shortened disease-free survival in univariate analysis. Pattern of staining - that is, nuclear versus cytoplasmic, did not influence patient survival. In vitro, down-regulation of the myc gene parallels increased cellular differentiation in a number of cell types. ${ }^{65}$ The relation in the present study between $\mathrm{p} 62^{\mathrm{c}-\mathrm{myc}}$ levels and tumour phenotype is in keeping with this. Several other immunohistochemical and molecular studies using northern blotting to quantify c-myc RNA transcripts have not demonstrated an association between myc and survival. ${ }^{66}{ }^{67}$ Further work is required, therefore, to substantiate or discount the findings in the present study. Increased staining for $\mathrm{p} 62^{\mathrm{c}-\mathrm{myc}}$ was evident in both adenomas and carcinomas. Consequently, like bcl-2 deregulation, overexpression of the myc oncoprotein is an early event in colorectal tumorigenesis. No relation was found between c-myc and bcl-2 expression, which 
seemed to occur as independent events. This is despite the fact that in vitro and in transgenic mice, there is substantial evidence for cooperation between these two genes in neoplastic transformation of lymphoid and fibroblast cell lines. ${ }^{11-13}$ It may be that this form of cooperation is not a feature of large bowel carcinogenesis.

In conclusion, the development of colorectal cancer is a multistep process during which a series of genetic lesions accumulate. Many of these events involve oncogenes and tumour suppressor genes, several of which have been identified, and seem to be preferentially altered at different points in the adenoma-carcinoma sequence. In this study we have documented changes in the expression of the bcl-2 and c-myc proto-oncogenes, both of which are overexpressed in adenomas. While c-myc expression persists in the majority of carcinomas however, expression of bcl-2 is absent in all but 10 to $30 \%$ of tumours. In previous studies we have reported p53 accumulation and k-ras mutation in 46 and $24 \%$ of colonic carcinomas, respectively, as well as 5 and $27 \%$ of adenomas. ${ }^{27}{ }^{28}$ Mutations in the k-ras gene occur with adenoma progression, and are found more commonly in large, severely dysplastic polyps, whereas lesions in the p53 gene arise around the time of adenomacarcinoma transition. Further work on the complex interaction between genes regulating cell proliferation, differentiation and programmed cell death will provide new insights into the mechanism of large bowel carcinogenesis and may eventually guide the selection of cytotoxic therapy in these and other tumours.

Thanks are due to Miss W Bloor, Miss J Hamblin, Mr S Toms, and $\mathrm{Mr} \mathrm{A}$ Hay for their help in the production of this manuscript.

1 Steel GG. Growth kinetics of tumours. London: Oxford University Press, 1977

2 Kerr JFR, Winterford CM, Harmon BV. Apoptosis. Its significance in cancer and cancer therapy. Cancer 1994, 73:2013-26

3 GavrieliY, ShermanY, Ben-Sasson SA. Identification of programmed cell death in situ via specific labelling of nuclea DNA fragmentation. $\mathcal{F}$ Cell Biol 1992;119:493-501.

4 Lee FD. Importance of apoptosis in the histopathology of drug related lesions in the large intestine. $\mathcal{F}$ Clin Pathol 1993;46:118-22.

5 Epstein RJ, McDonald GB, Sale GE, Shulman HM, Thomas ED. The diagnostic accuracy of the rectal biopsy in acute graft-versus-host disease: a prospective study of thirteen patients. Gastroenterology 1980;78:764-71.

6 Hoffman B, Liebermann DA. Molecular controls of Hoffman B, Liebermann DA. Mol
apoptosis. Oncogene 1994;9:1807-12.

7 Tsujimoto Y, Croce CM. Analysis of the structure, transcripts and protein products of bcl-2, the gene involved in human follicular lymphoma. Proc Natl Acad Sci USA 1986;83:5214-18

8 Akao Y, Otsuki Y, Kataoka S, Ito Y,Tsujimoto Y. Multiple subcellular localization of bcl-2: detection in nuclear outer membrane, endoplasmic reticulum and mitochondrial membranes. Cancer Res 1994;54:2468-71.

9 Vaux DL, Cory S, Adams JM. Bcl-2 gene promotes haemopoeitic cell survival and cooperates with c-myc to immorpoeitic cell survival and cooperates with c-m

10 McDonnell TJ, Deane N, Platt FM, Nunez G, Jaeger U, McKearn JP, Korsmeyer SJ. Bcl-2-immunoglobulin transgenic mice demonstrate extended $\mathrm{B}$ cell survival and folligenic mice demonstrate extended B cell survival
cular lymphoproliferation. Cell 1989;57:79-88.

11 McDonnell TJ, Korsmeyer SJ. Progression from lymphoid hyperplasia to high-grade malignant lymphoma in mic transgenic for the $t(14 ; 18)$. Nature $1991 ; 349: 254-6$.

12 Bissonnette RP, Echeverri F, Mahboubi A, Green DR. Apoptotic cell death induced by c-myc is inhibited by bcl- 2 . Nature 1992;359:552-4.

13 Fanidi A, Harrington EA, Evan GI. Cooperative interaction between c-myc and bcl-2 proto-oncogenes. Nature 1992 359:554-6.

14 Hague A, Moorghen M, Hicks D, Chapman M, Paraskeva C. Bcl-2 expression in human colorectal adenomas and carcinomas. Oncogene 1994;9:3367-70.
15 Sinicrope FA,Ruan S, Cleary KR, Stephens LC, Lee JJ, Leven B. Bcl-2 and p53 oncoprotein expression during colorectal tumorigenesis. Cancer Res 1995;55:237-41.

16 Finley GG, Schulz NT, Hill SA, Geiser JR, Pipas JM, Meisler AI. Expression of the myc gene family in different stages of human colorectal cancer. Oncogene 1989;4:963 71

17 Smith DR, Myint T, Goh HS. Over expression of the c-myc proto-oncogene in colorectal carcinoma. $\mathrm{Br} \mathcal{F}$ Cancer 1993;68:407-13

18 Evan GI, Wyllie AH, Gilbert CS, Littlewood TD, Land H, Brooks $\mathrm{M}$, et al. Induction of apoptosis in fibroblasts by c-myc protein. Cell 1992;69:119-28.

19 Baker SJ, Preisinger AC, Jessup JM, Paraskeva C, Markowitz $S$, Willson JKV, et al. p 53 gene mutations occur in com-
binations with $17 \mathrm{p}$ allelic deletions as late events in colorectal tumorigenesis. Cancer Res 1990;50:7717-22.

20 Shaw P, Tardy S, Benito E, Obrador A, Costa J. Occurrence of ki-ras and p53 mutations in primary colorectal tumors. Oncogene 1991;6:2121-8.

21 Rodrigues NR, Rowan A, Smith MEF, Kerr IB, Bodmer WF, Gannon JV, Lane DP. p53 mutations in colorectal cancer. Proc Natl Acad Sci USA 1990;87:7555-9.

22 Baas IO, Mulder J, Offerhaus GJ, Vogelstein B, Hamilton SR. An evaluation of six antibodies for immunohistochemistry of mutant $\mathrm{p} 53$ gene product in archival colorectal neoplasms. F Pathol 1994;172:5-12.

23 Shaw P, Bovey R, Tardy S, Sahli R, Sordat B, Costa J. Induction of apoptosis by wild type p53 in a human colon tumor derived cell line. Proc Natl Acad Sci USA 1992;89:4495-9.

24 Miyashita T, Krajewski S, Krajewski M, Wang H, Lin HK Liebermann DA, et al. Tumour suppressor p53 is a regulator of bcl-2 and bax gene expression in vitro and in vivo. Oncogene 1994;9:1799-805.

25 Fujiwara T, Grimm EA, Mukhopadhyay T, Zhang W, Owen-Schaub LB, Roth JA. Induction of chemosensitivity in human lung cancer cells in vivo by adenovirus-mediated transfer of the wild type p53 gene. Cancer Res 1994 54:2287-91.

26 Lowe SW, Bodis S, McCatchey A, Remington L, Ruley HE, Fisher DE, et al. p53 status and the efficacy of cancer therapy in vivo. Science 1994;266:807-10

27 Bell SM, Scott N, Cross D, Sagar P, Lewis FA, Blair GE, et al. Prognostic value of p53 over expression and c-ki-ras gene mutations in colorectal cancer. Gastroenterology 1993 104:57-64.

28 Scott N, Bell SM, Sagar P, Blair GE, Dixon MF, Quirke P. p53 expression and k-ras mutation in colorectal adenomas. Gut 1993;34:621-4.

29 Jass JR, Morson BC. Reporting colorectal cancer. 7 Clin Pathol 1987;40:1016-23.

30 Williams NS, Jass JR, Hardcastle JD. Clinicopathological assessment and staging of colorectal cancer. $\mathrm{Br} \mathcal{F}$ Surg 1988;75:649-52.

31 Hedley DW, Friedlander ML, Taylor IW, Rugg CA Musgrove EA. Method for analysis of cellular DNA content of paraffin-embedded pathological material using flow cytometry. F Histochem Cytochem 1983;31:1333-5.

32 Bagwell CB. Theory and application of DNA histogram analysis [PhD thesis]. Miami (FL): University of Miami, 1979 .

33 Hiddemann W, Schumann J, Andreef M, Barlogie B Herman CJ, Leif RC, et al. Convention on nomenclature for DNA cytometry. Cytometry 1984;5:445-6.

34 Konishi F, Morson BC. Pathology of colorectal adenomas: a colonoscopic survey. $\mathcal{f}$ Clin Pathol 1982;35:830-41.

35 Pezzella F, Tse AGD, Cordell JL, Pulford KAF, Gatter KC, Mason DY. Expression of the bcl-2 oncogene protein is not specific for the $14 ; 18$ chromosomal translocation. $A m ~ F$ Pathol 1990;137:225-32.

36 Evan GI, Lewis GK, Ramsay G, Bishop JM. Isolation of monoclonal antibodies specific for human c-myc protooncogene product. Mol Cell Biol 1985;5:3610-16.

37 Gurney EG, Harrison RO, Fenno J. Monoclonal antibodies against simian virus $40 \mathrm{~T}$ antigens. $\mathcal{F}$ Virol 1980;34:75263.

38 Banks L, Mathashewski G, Crawford L. Isolation of human p53-specific monoclonal antibodies and their use in studp53-specific monoclonal antibodies and their use in stud159:529-35.

39 Scott N, Quirke P. Molecular biology of colorectal neoplasia. Gut 1993;34:289-92.

40 Radinsky R, Fidler IJ, Price JE, Esumi N, Tsan R, Petty $\mathrm{CM}$, et al. Terminal differentiation and apoptosis in experimental lung metastases of human osteogenic sarcoma cells by wild type p53. Oncogene 1994;9:1877-83.

41 Miyashita T, Reed JC. Bcl-2 gene transfer increases relative resistance of S49.1 and WEH17.2 lymphoid cells to cell death and DNA fragmentation induced by glucocorticoids and multiple chemotherapeutic drugs. Cancer Res 1992; 52:5407-11.

42 Lowe SW, Ruley H, Jacks T, Housman DE. p53 dependent apoptosis modulates the cytotoxicity of anticancer agents Cell 1993;74:957-67.

43 Kinzler KW, Vogelstein B. Cancer therapy meets p53: clinical implications of basic research. $N$ Engl $\mathcal{f} \mathrm{Med}$ 1994;331:49-50.

44 Merritt AJ, Potten CS, Kemp CJ, Hickman JA, Balmain A, Lane DP, Hall PA. The role of p53 in spontaneous and radiation-induced apoptosis in the gastrointestinal tract of normal and p53 deficient mice. Cancer Res 1994;54:614-17. 
45 Hockenbery DM, Zutter M, Hickey W, Nahm M, Korsmeyer SJ. Bcl-2 protein is topographically restricted in tissues characterised by apoptotic cell death. Proc Natl Acad Sci USA 1991;88:6961-5.

$46 \mathrm{Lu} \mathrm{Q}$, Poulsom R, Wong L, Hanby AM. Bcl-2-expression in adult and embryonic non-haematopoietic tissues. $\mathcal{f}$ Pathol 1993;169:431-7.

47 Hamilton SR. Molecular genetics of colorectal carcinoma. Cancer 1992;70:1216-21.

48 Pretlow TP, Bartrow BJ, Ashton WS, O'Riordan MA, Pretlow TG, Jurcisek JA, Stellatao TA. Aberrant crypts: putative pre-neoplastic foci in human colonic mucosa. Cancer Res 1991;51:1564-7.

49 Risio M, Coverlizza S, Ferrari A, Candalaresi GL, Rossini FP. Immunohistochemical study of epithelial cell proliferation in hyperplastic polyps, adenomas and adeno94:899-906.

50 Reed JC, Tsujimoto Y, Alpers JD, Croce DM, Nowell PC. Regulation of bcl-2 proto-oncogene expression during normal human lymphocyte proliferation. Science 1987; 236:1295-9.

51 Mateo MS, Sanchez-Beato M, Martinez JC, Orfao A, Orradre JL, Piris MA. P53, Rb and bcl-2 expression during the cell cycle: a study in phytohaemaglutinin stimulated lymphocytes and microwave irradiated lymphoid tissue sections. F Clin Pathol 1995;48:151-9.

52 Kaklamanis L, Savage A, Tsiotis P, Biddolph SC, Mortensen N, Harris AL, Gatter KC. The expression of bcl-2 oncoprotein in colorectal neoplasia (abstract). $\mathcal{F}$ Pathol 1994;173:S165A.

53 Hanada M, Krajewski S, Tanaka S, Cazals-Hatem D, Spengler BA, Ross RA, et al. Regulation of bcl-2 oncoprotein levels with differentiation of human neuroblastoma cells. Cancer Res 1993;53:4978-86.

54 Pilotti S, Collini P, Rilke F, Cattoretti G, Bo R, Pierotti M. $\mathrm{Bcl}-2$ protein expression in carcinomas originating from the follicular epithelium of the thyroid gland. $\mathcal{F}$ Pathol 1994;172:337-342.

55 Leek RD, Kaklamanis L, Pezzella F, Gatter KC, Harris AL Bcl-2 in normal human breast and carcinoma, association with oestrogen receptor positive, epidermal growth factor receptor negative tumours and in situ cancer. Br $\mathcal{F}$ Cancer 1994;69:135-9.
56 Van den Berg FM, Tigges AJ, Schipper MEI, Den Hartog Jeger FCA, Kroes WGM, Walboomers JMM. Expression of the nuclear oncogene p53 in colon tumours. 7 Pathol 1989;157:193-9.

57 Cunningham J, Lust JA, Schaid DJ, Bren GD, Carpenter HA, Rizza E, et al. Expression of p53 and $17 \mathrm{p}$ allelic loss in colorectal carcinoma. Cancer Res 1992;52:1974-80.

58 Kaklamanias L, Gatter KC, Mortensen N, Baigrie RJ, Heryet A, Lane DP, Harris AL. p53 expression in colorectal adenomas. Am f Pathol 1993;142:87-93.

59 Haldar S, Negrini M, Monne M, Sabbioni S, Croce C. Down regulation of bcl-2 by p53 in breast cancer cells. Cancer Res 1994;54:2095-7.

60 Wyllie AH, Rose KA, Morriss RG, Steel CM, Foster E, Spandidos DA. Rodent fibroblast tumours expressing Spandidos DA. Rodent fibroblast tumours expressing human myc and ras genes: growth, metastasis and endo-

genous oncogene expression. Br f Cancer 1987;56:251-9.
61 Vogelstein B, Fearon ER, Hamilton SR, Kern SE, Preisinger AC, Leppert M, et al. Getic tumor development. N Engl F Med 1988;319:525-32.

62 Burmer GC, Loeb LA. Mutations in the kras2 oncogene during progressive stages of human colon carcinoma. Proc Natl Acad Sci USA 1989;86:2403-7.

63 Williams ARW, Piris J, Wyllie AH. Immunohistochemical demonstration of altered intracellular localisation of the
c-myc oncogene product in human colorectal neoplasms. $\mathcal{F}$ c-myc oncogene product in
Pathol 1990;160:287-93.

64 Melhem MF, Meisler AI, Finley G, Bryce WH, Jones MO Tribby II, et al. Distribution of cells expressing myc proteins in human colorectal epithelium, polyps and malignant tumours. Cancer Res 1992;52:5853-64

65 Taylor CW, Kim YS, Childress-Fields KE, Yeoman LC. Sensitivity of nuclear c-myc levels and induction to differentiasitivity of nuclear c-myc levels and induction to differentiation inducing agents in humar

66 Jones DJ, Ghosh AK, Moore M, Schofield PF. A critical appraisal of the immunohistochemical detection of the c-myc oncogene product in colorectal cancer. $\mathrm{Br} \mathcal{F}$ Cancer 1987;56:779-83.

67 Erisman MD, Litwin S, Keidan RD, Comis RL, Astrin SM Non correlation of the expression of the c-myc oncogene in colorectal carcinoma with recurrence of disease or patient survival. Cancer Res 1988;48:1350-5. 